Discussion Paper No. 08-084

\title{
The Effects of Experience on Selecting Innovation Projects - Better the Devil You Know
}

Tobias Schmidt, Franz Schwiebacher, and Wolfgang Sofka

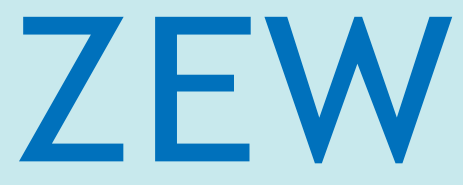

Zentrum für Europäische Wirtschaftsforschung $\mathrm{GmbH}$

Centre for European

Economic Research 
Discussion Paper No. 08-084

\title{
The Effects of Experience on Selecting Innovation Projects - Better the Devil You Know
}

\author{
Tobias Schmidt, Franz Schwiebacher, \\ and Wolfgang Sofka
}

Download this ZEW Discussion Paper from our ftp server:

ftp://ftp.zew.de/pub/zew-docs/dp/dp08084.pdf

Die Discussion Papers dienen einer möglichst schnellen Verbreitung von neueren Forschungsarbeiten des ZEW. Die Beiträge liegen in alleiniger Verantwortung der Autoren und stellen nicht notwendigerweise die Meinung des ZEW dar.

Discussion Papers are intended to make results of ZEW research promptly available to other economists in order to encourage discussion and suggestions for revisions. The authors are solely responsible for the contents which do not necessarily represent the opinion of the ZEW. 


\section{Non-technical summary}

Investing in innovation is a highly uncertain endeavour. Therefore, a common approach to mitigating the high risk of failure of a single project is to establish a portfolio of innovation projects and to select the most promising when implementing them. In the following, we investigate which types of experience generated by previous innovation projects could possibly improve firms' ability to judge the prospects of innovation projects' success and thereby identify and discard the less favourable opportunities.

We combine the insights of two management approaches: learning and selectionism (Loch et al, 2008; Pich et al, 2002), as discussed in the literature, to factor in environmental uncertainty in order to uncover the effects of previous innovation experiences on project selection. The first approach is one of trial and error. The information signals emerging from the different projects are used to update expectations of project success and environmental development. The selectionism approach, on the other hand, suggests dealing with environmental uncertainty by running multiple projects simultaneously. The insights of these management approaches are echoed, respectively, in economics in the theoretical concepts of "real options" and "absorptive capacity" rationale. These concepts are used to derive two major learning mechanisms from previous innovation experience.

The existence of a portfolio of projects leads us directly to the real options rationale. Based on this approach, we derive one learning mechanism from previous innovation experience. A single project is considered an option in the sense that it provides the firm with a right but not the obligation to pursue it further. Thus, the decision as to whether or not to complete the innovation projection can be postponed. The management recommendations delivered by the selections approach can be based on the theoretical premises of this concept. A learning mechanism is also derived from these premises. As the real options concept is derived from financial pricing models, the necessary information for deriving the value of individual projects, and therefore evaluating and deciding whether to pursue them or not, are the financial features of the innovation project. Thus, previous investments in innovation should increase the ability of firms to judge potential projects in terms of their economic feasibility.

The absorptive capacity literature, on the other hand, suggests learning from previous innovation experience - or more specifically, R\&D experience - thus improving firms' ability to identify, assimilate and exploit external knowledge. The absorptive capacity of a firm therefore describes its ability to process external information signals, and this ability enables the firm to predict future technological and market trends more accurately. This is similar to updating expectations about future developments in the trial and error management approach. Based on this comprehensive knowledge base, previous innovation experience enhances firms' ability to judge innovation projects in terms of their knowledge requirements and to decide on this basis whether to pursue them or not.

We test for the existence of these different learning mechanisms of innovation experience for judging the likelihood of project success empirically on the basis of data from the 
Mannheim Innovation Panel. First, we analyse the project selection criteria reported by surveyed heads of R\&D departments and investigate whether the observed reasons for abandoning or not starting innovation projects reflect the underlying constructs of the learning mechanisms or the judgement of projects on the basis of economic feasibility or knowledge requirements. The analysis of principal component factors confirms our theoretical reasoning as we obtain two distinct factors representing two distinct dependence structures among the possible reasons for not further pursuing the innovation project. The first - hereinafter referred to as the economic factor - represents the dependence between selection reasons based solely on financial considerations, eg lack of external funding. The second - hereinafter referred to as the knowledge factor - represents the dependence between selection reasons based solely on judging projects in terms of knowledge requirements, e. g. lack of market or technological information. These two distinct dependence structures thus confirm the existence of the two learning mechanisms that we derived theoretically above.

We conduct an econometric analysis subsequently, in order to reveal which type of experience is actually generated by previous innovation experience. Thereby, the (orthogonalised and rescaled) principal component factors serve as instruments for the two types of experience generated. Our results indicate congruence between firms' innovation experience and their project selection patterns. Previous innovation experience, measured by lagged innovation intensities, appears to have a positive and significant impact on project selection based on economic factors. However, there are no such effects with respect for the knowledge factor. The effect holds once we split innovation expenditure into R\&D and laterstage innovation expenditure as different types of innovation expenditure in different phases of the innovation process should produce different kinds of feedback experience. This is also reflected in our regression results when we split all innovation expenditure into $R \& D$ and non-R\&D expenditure. Thus, R\&D expenditure, as investments in absorptive capacity, enhances firms' ability to judge projects in terms of their knowledge requirements and nonR\&D, whereas later-stage innovation expenditure are reflected in project selection based on economic factors. 


\section{Das Wichtigste in Kürze (Summary in German)}

Aufwendungen für Innovationsaktivitäten sind für die durchführenden Unternehmen mit einem hohen betriebswirtschaftlichen Risiko verbunden. Unternehmen diversifizieren deshalb üblicherweise das Risiko über verschiedene Innovationsprojekte. Im Zeitablauf sollten demnach Projekte, die sich als wenig erfolgversprechend erweisen, selektiert werden. Ziel dieses Diskussionsbeitrags ist die Analyse, ob Erfahrungen aus bereits implementierten Innovationen sich in der Fähigkeit des Unternehmens niederschlagen, die Erfolgsaussichten einzelner Projekte zu eruieren, die wenig erfolgversprechenden zu identifizieren und diese somit aus dem Projektportfolio zu selektieren.

Um mögliche Mechanismen zu identifizieren, wie sich Innovationserfahrung auf die Selektion von Projekten auswirkt, greifen wir zunächst auf die Managementansätze ,learning' und ,selectionism' zum Umgang mit inhärenter Unsicherheit zurück. Die Implikationen der beiden Managementansätze, nämlich der Risikodiversifikation über verschiedene Projekte bzw. der permanenten Aktualisierung der Informationsbasis, spiegeln sich auch in den theoretischen Konstrukten der 'real options' und der 'absorptive capacity' wider. Diese werden wir für die Herleitung potentieller Lernmechanismen zur Selektion von Innovationsprojekten heranziehen.

Einzelne Innovationsprojekte können zum einen als Option betrachtet werden, im dem Sinne, dass ein Recht erworben wird sich in dem jeweiligen technologischen Feld weiter zu engagieren. Da damit aber keine Verpflichtung zur Fortführung des Projekts einhergeht und sich der Wert dieser Option aus finanziellen Daten der Investitionsrechnung ergibt, impliziert dieser Theoriestrang, dass potentielle Lerneffekte aus früherer Innovationstätigkeit aus der verbesserten Fähigkeit resultieren, Projekte unter dem Blickwinkel finanzieller Machbarkeit zu evaluieren, und damit zu selektieren.

Auf der anderen Seite ist mit Innovations- (bzw. dabei insbesondere FuE-) Tätigkeiten auch ein Aufbau absorptiver Fähigkeiten verbunden, d. h. einer verbesserten Fähigkeit externes Wissen $\mathrm{zu}$ erkennen, $\mathrm{zu}$ integrieren und nutzbar $\mathrm{zu}$ machen. Da somit durch bereits implementierte Innovationen c. p. mehr potentielle externe Wissensquellen identifiziert worden sind. Dies erleichtert die Evaluation von Innovationsprojekten auf Basis des, für deren Fortführung benötigten Wissens, welches technologischer Art oder Wissen über Marktgegebenheiten sein kann.

Auf Basis des Mannheimer Innovationspanels untersuchen wir empirisch ob bzw. welche Lerneffekte sich bezügl. der Selektion von Innovationsprojekten nachweisen lassen. Dazu analysieren wir zunächst die Struktur der Hemmnisfaktoren von denen die befragten Leiter der FuE-Abteilungen angeben, dass sie zu einem Abbruch oder zu einer Einstellung des Innovationsprojekts bereits in der Konzeptionsphase geführt haben. Es zeigt sich, dass die zwei oben theoretisch postulierten Lernmechanismen sich auch empirisch widerspiegeln. In einer Hauptkomponentenanalyse kristallisieren sich zwei disjunkte Abhängigkeitsstrukturen zwischen den potentiellen Selektionsmotiven heraus. Unternehmen selektieren demnach 
Innovationsprojekte entweder aus dem Blickwinkel der finanziellen Machbarkeit oder aus dem Blickwinkel fehlenden Wissens bzw. Kenntnisse aus. Diese (orthogonalisierten und normierten) Faktoren der Hauptkomponentenanalyse dienen uns dann als Instrumente für die zwei Arten potentieller Lernmechanismen. Sie bilden dann unsere abhängige Variable in einer Regression, um zu zeigen welche Lerneffekte aus früherer Innovationstätigkeit tatsächlich resultieren. Es zeigt sich, dass Erfahrungen aus vergangenen Innovationsprojekten, abgebildet durch die zeitverzögerten Innovationsintensitäten der Unternehmen, einen signifikant positiven Einfluss auf die Selektion von Projekten aus finanzwirtschaftlichen Beweggründen aufweisen. Frühere Innovationstätigkeit hat dabei keinen Effekt auf die Selektion wenig erfolgversprechender Projekte auf Grund fehlenden Wissens oder Kenntnisse. Ein differenzierteres Bild zeigt sich, wenn man die Innovationstätigkeit entlang verschiedener Stufen des Innovationsprozesses differenziert (d. h. zwischen grundlagenorientierter FuETätigkeit und anwendungsbezogener Innovationstätigkeit). Aufwendungen für FuE erhöhen demnach, als Investitionen in die absorptive Kapazität, die Fähigkeit Innovationsprojekte auf Basis des, für deren Fortführung benötigten Wissens und Kenntnisse zu evaluieren. Aufwendungen für die nachfolgenden Stufen des Innovationsprozesses sind demgegenüber mit einem Erfahrungsgewinn in der Evaluation der finanziellen Machbarkeit verbunden ist. Verschiedene Stufen des Innovationsprozesses generieren somit auch unterschiedliche Erfahrungen. 


\title{
The Effects of Experience on Selecting Innovation Projects - Better the Devil You Know
}

\author{
Tobias Schmidt ${ }^{\mathrm{a}}$, Franz Schwiebacher ${ }^{\mathrm{b}}$ and Wolfgang Sofka ${ }^{\mathrm{b}}$ \\ ${ }^{a}$ Deutsche Bundesbank, Frankfurt am Main, Germany \\ ${ }^{\mathrm{b}}$ Centre for European Economic Research (ZEW), Mannheim, Germany
}

\begin{abstract}
Innovation success depends heavily on firm's ability to set priorities and select the most promising options from its project portfolio before the odds of success or failure become visible and reliable. We ask: What does previous innovation experience tell firms about what not to do in the future? With this in mind, we focus on projects that did not materialise or were abandoned - an important building block for choosing and implementing the "right" projects. We suggest two major learning mechanisms. On the one hand, real options theory suggests a process based on financial data. On the other hand, research on absorptive capacities finds that previous innovation experience translates into superior ability to value, extract and exploit external knowledge. We test both hypotheses on an empirical basis for more than 600 German firms, covering innovation activities in the period 1997 to 2005. Our results indicate congruence between firms' innovation experience and their project selection patterns. Extensive R\&D experience materialises as a stock of knowledge that enables firms to judge projects based on knowledge criteria. Non-R\&D innovation experience, stemming from producing and introducing products to markets, resonates as decision-making based on economic factors in the future. Both types of innovation experience appear to generate distinct decision-making capabilities inside the firm which are subsequently exploited in selecting projects for the future.
\end{abstract}

Keywords: Project selection, real options, absorptive capacity

JEL-Classification: F23, O31, O32, D83

Disclaimer: Discussion Papers represent the authors' personal opinions and do not necessarily reflect the views of the Deutsche Bundesbank or its staff.

Corresponding author:

Franz Schwiebacher

Schwiebacher@zew.de

Phone: +49/621/1235-234, Fax: +49/621/1235-170

Centre for European Economic Research (ZEW)

Department of Industrial Economics and International Management

P.O. Box 1034 43, D-68034 Mannheim, Germany 



\section{$1 \quad$ Introduction}

Generating competitive advantage through the continuous introduction of new products, services and processes is the core challenge for most firms in modern economies. However, the recipe for successful innovation activities remains unclear. $40 \%$ to $90 \%$ of new products fail (depending on category), and this rate has remained relatively stable over the last 25 years (Gourville, 2006). Hence, innovation engagements remain an uncertain endeavour, ie the odds of success are difficult if not impossible to predict. Most firms tackle this issue by engaging in multiple innovation projects so that they have a broad spectrum of possible solutions. This approach implies that they are able to set priorities and select the most promising options once the odds of success or failure become visible and reliable.

Most research in the field focuses on the technological options that have actually materialised as new products or processes, partly because they are traceable through patent applications or sales numbers. We add to this body of literature by arguing that an important part of picking the winning projects lies in a firm's ability to identify and discard less favourable innovation opportunities. The latter enables firms to concentrate scarce resources once probabilities for success or failure have emerged. More precisely, we explore the type of knowledge firms generate from previous investments in innovation activities that enables them to decide on which projects not to pursue or no longer to pursue. We develop the hypotheses based on two streams of literature: real options theory and absorptive capacity research. We suggest that learning from previous investments in innovation reduces uncertainties deriving from economic factors and/or knowledge deficits. Both should be reflected in a firm's project selection. Furthermore, we argue that both the stage of innovation activities (R\&D activities vs activities close to market introduction) and the related learning experience influence the selection criteria. We test these hypotheses empirically for more than 750 German firms and their innovation activities between 1997 and 2005.

The remainder of this paper is organised as follows. Section 2 provides our theoretical framework on uncertainty and project selection, followed by the hypotheses development. Section 4 outlines the empirical study while section 5 presents the results. We conclude by discussing them in section 6 and providing an outlook on future research. 


\section{Uncertainty in innovation activities and project selection}

Innovation activities are investments in the future and therefore the outcome is uncertain, ie it is dependent on changes in the environment and the perception of the initial state of the environment. Evaluating individual innovation projects is challenging because of dynamic opportunities, project interdependencies, multiple goals and strategy considerations, unreliable or changing information and multiple decision makers (Cooper et al., 2001). There is a variety of definitions, constructs and subsequent measures of the dimensions of uncertainty. Knight (1921) provides a basic definition of uncertainty as the absence of probability distributions, ie no probabilities on multiple outcomes in a certain situation can be calculated. This stream of literature focuses on the lack of information on the environment and causal relationships (eg Lawrence and Lorsch, 1967) as a cause of uncertainty. Hence, traditional risk management methods do not apply. Innovation success depends on the complex interplay between the actions undertaken by firms and the state of the environment (Loch et al, 2008; Pich et al, 2002). Managers are typically unaware of many potential influential factors at the beginning of the innovation process. As these factors are unknown, nothing to say of their "sample realisation" during the innovation process, they cannot be incorporated in the risk management of the innovation process.

The major goal of our analysis is to focus on how firms deal with uncertainty in their innovation activities. Literature suggests two general approaches: selectionism and learning (Loch et al, 2008; Pich et al, 2002). The learning perspective suggests a flexible approach of trial and error in which firms set expectations but are constantly ready and willing to update and change them once signals emerge that they are not in line with reality (see, for example, Chesbrough and Rosenbloom, 2002; O'Connor and Veryzer, 2001). However, selectionism implies that firms pursue multiple options simultaneously and accept that some will eventually fail. McGrath, 2001 describes this process as "variance seeking" instead of "mean seeking" for new opportunities. Such a portfolio of innovation projects allows firms facing an uncertain environment to balance individual risks, align innovation engagements with the overall business strategy and maximise the returns on R\&D spending (Cooper et al, 2001).

Our goal is to extend this existing literature by combining the perspectives of learning and selectionism. The management of innovation portfolios under uncertainty is a dynamic decision process built around evaluating, selecting and prioritising projects so that resources can be efficiently allocated (Cooper et al, 2001). Management literature has to a large extent dealt with the issue from the perspective of how quantitative and/or qualitative tools can facilitate the management of innovation portfolios given the uncertainty challenges (see, for example, Copeland and Tufano, 2004; Maher and Rubenstein, 1974 and Heidenberger and Stummer, 1999 for a comprehensive review). However, relatively little is known about how experience from previous innovation initiatives shapes a firm's project selection. We aim at contributing to the literature by assessing the value of these previous learning engagements in relation to a firm's decision to reject or discontinue projects, ie to weed bad projects out of their portfolio. 


\section{$3 \quad$ Hypotheses development}

We explore two streams of literature - real options theory and absorptive capacity research to capture the potential effects of learning from previous innovation engagements on current project selection theoretically.

\subsection{Investments in innovation activities as real options}

"The valuation of investments in R\&D projects is a crucial topic in R\&D management" (Perlitz et al, 1999: 255) is the opening line of the paper by Perlitz et al which discusses the application of the real options evaluation method to innovation and R\&D activities. The real options method is based on financial option pricing models (Black and Scholes, 1973). Real options are sequential, irreversible investments in real assets made under uncertainty (Adner and Levinthal, 2004; Pindyck, 1991) and provide firms with the right but not the obligation to pursue certain actions in the future (Folta and O'Brien, 2004). Since the real options approach is tailored to deal with the uncertainty involved in investment decisions and projects (Trigoergis, 1997), its application to R\&D and innovation projects involving high levels of uncertainty is not surprising. Investments in innovation activities produce real options for dealing with environmental dynamics through the build-up of internal capabilities and knowledge stocks. By holding a real option, a firm secures only its access to a given innovation project in the future. Innovation projects typically require substantial investments, but holding the comparatively cheap option enables the firm to postpone its decision to undertake a project. Own internal innovation and $R \& D$ activities may therefore function like an insurance policy in the sense that firms can reduce their overall exposure to uncertainty by holding several real options. Similar to the rational logic behind financial options, real options can serve as a method of reducing the risk of substantial losses for a given financial return (Perlitz et al, 1999). Options can take different forms which can be exercised if the innovation and R\&D projects do not develop as expected (see Perlitz et al, 1999 for an excellent review). These options include, among other things, stopping a project completely, putting a project on hold to wait for new information or reducing the size of the project (see, for example, Kester, 1984, Trigeorgis, 1993).

A real options portfolio presents a method of insurance against the uncertainty involved in R\&D projects if project evaluations are constantly updated and refined. Perlitz et al (1999) present a detailed review of the different ingredients needed to come up with a valuation of a given $R \& D$ project based on option pricing models like the binominal model or the BlackScholes model. The necessary elements are the exercise price, the time to expiration, the risk involved, the dividend payment, and the risk less interest rate. All these factors are clearly related to economic or, to be more precise, financial features of an $R \& D$ project. Thus the more $R \& D$ and innovation projects a firm undertakes, the more experience and points of reference it should have for evaluating these projects with regard to their economic feasibility. We therefore derive: 
Hypothesis 1: Previous investments in innovation increase the ability of firms to judge potential projects in terms of their economic feasibility.

\subsection{Investments in absorptive capacity as uncertainty-reducing instruments}

Investments in $R \& D$ not only generate real option-related learning experience, ie they not only clarify economic factors. A different but related stream of research sees R\&D investments' primary benefit as the ability to acquire new knowledge and technologies. As Cohen and Levinthal $(1989 ; 1990)$ have shown, they increase firms' absorptive capacity. Absorptive capacity consists of three elements (Cohen and Levinthal, 1989; 1990): The identification of valuable knowledge in the environment, its assimilation in existing knowledge stocks and finally its exploitation for successful innovation. Absorptive capacities, their roots, mechanisms and consequences have been an extensive part of recent scientific discussions (Lane et al, 2006 have 289 papers in their excellent review). High absorptive capacities enable firms to engage in exploratory innovation activities through unpredictable or rare combinations of existing technology or knowledge (Jansen et al, 2006; Subramaniam and Youndt, 2005). They also provide the basis for reinforcing, complementing or refocusing a firm's knowledge base (Lane et al, 2006). Investments in absorptive capacities give them access to a rich set of diverse knowledge which provides firms with more choices to solve problems and to react to environmental changes (Bowman and Hurry, 1993; March, 1991). Zahara and George (2002) introduce the distinction between potential and realised absorptive capacity. In essence, they imagine absorptive capacity to be the interplay of organisational processes for bringing a broad range of diverse ideas into the firm, which are subsequently narrowed down, prioritised and codified to facilitate efficient assimilation, and exploitation processes (Jansen et al, 2005). Cohen and Levinthal (1994) suggest that absorptive capacities enable firms to predict future developments more accurately. Continuous learning engagements increase awareness for market and technology trends which can be translated into pre-emptive action. Firms may discover new and previously concealed challenges as their internal capacities for identifying, evaluating and developing them expand.

In summary, firms with high absorptive capacities are better able to assess the knowledge requirements of potential projects because they have a more comprehensive overview of potential knowledge sources and availability. What is more, they are experienced in evaluating the potential contributions of external knowledge for their internal innovation processes. Building on these arguments we hypothesise:

Hypothesis 2: Investments in innovation activities increase the ability of firms to judge projects in terms of their knowledge requirements.

\subsection{Investments at different stages of the innovation process}

The chain-linked model of innovation developed by Kline and Rosenberg (1986) is built around distinct stages of the innovation process. They distinguish between an invention phase, a redesign and production phase, and a distribution and market phase. Research of different kinds is a necessary ingredient for each phase. The OECD and Eurostat both acknowledge 
that the innovation process involves various steps and phases by writing "The point to be noted [...] is that innovation is a complex, diversified activity with many interacting components [...]" (OECD/Eurostat, 1997). Analogous to the different phases, different types of investments in innovation activities are necessary. The literature on input into the innovation process is a good way of illustrating this point. Felder et al (1996), for example, argue that, although expenditure on research and development is an important element of input for the process of developing innovative products or projects, it is not the only one. They, as well as Grupp (1997), make the case that other investments in innovation activities, such as expenditure on the acquisition of technology, licences or patents, which is necessary for the innovation process, also constitute important elements of input. These elements could still be expenditure in the early phases of innovation processes and are most often linked to R\&D activities. They all relate to access to relevant and complementary knowledge. The later phases of the innovation process, ie distribution and marketing of innovative products or the introduction of innovative processes in the firm also require substantial investments that go beyond $R \& D$ investments. These investments are particularly relevant for sectors of the economy not relying on internal R\&D extensively, ie service industries and small manufacturing firms in certain industries (see, for example, Kleinknecht, 1987; Pavitt et al, 1989; Hipp and Grupp, 2005). Brouwer and Kleinknecht (1997) show that the innovation activities close to the market do influence the success of innovations and are not covered by R\&D expenditure. The Community Innovation Surveys (CIS) of the member states of the European Union take this into account by asking firms about R\&D expenditure and non-R\&D innovation expenditure, such as investments in the acquisition of machinery and equipment and external knowledge for innovation activities or for the market introduction of innovations (see OECD/Eurostat 1997).

Different types of innovation expenditure in different phases of the innovation process should produce different kinds of feedback and add to the experience and lessons for a firm. We would therefore add an additional dimension to our previous hypotheses. We argue that technological R\&D investments facilitate learning about technological opportunities or threats. This should be applied to project selection based on knowledge criteria. Innovation expenditure close to market introduction, however, provides lessons on market conditions and necessities. This experience should translate into project selection based on economic factors. Our formal hypotheses are:

Hypothesis 3a: Investments in $R \& D$ (early stages) increase the ability of firms to judge projects in terms of their knowledge requirements.

Hypothesis 3b: Investments in non-R\&D innovation activities (late stages) increase the ability of firms to judge potential projects in terms of their economic feasibility. 


\section{$4 \quad$ Empirical study}

\subsection{Estimation strategy}

The main idea of our empirical set-up is to capture managers' project selection criteria by observing the reasons why they either abandon ongoing innovation projects or do not start new ones. The assumption behind this approach is that firms reveal their preference for project evaluation - ie economic feasibility or knowledge requirements - in the reasons they give (out of a total of seven different options) for not starting or abandoning innovation projects. To provide an example by way of clarification: we assume that a firm stating high innovation costs as a reason for not starting innovation activities pays more attention to economic factors than a firm stating that a lack of technological knowledge is responsible for not starting innovation projects. Our estimation strategy has three major stages:

- We investigate whether seven observed reasons for abandoning or not starting innovation projects reflect the underlying constructs of project selection based on economic or knowledge criteria. We perform confirmatory factor analyses for this purpose. The resulting factor scores serve as the dependent variables in all further investigations.

- We relate innovation activities in previous time periods to the project selection constructs derived in the first step of the empirical analysis through regression analyses to test hypotheses 1 and 2 .

- We differentiate between $R \& D$ and non-R\&D experiences in previous time periods and their effects on the project selection constructs derived in the first step of the empirical analysis through regression analyses to test hypotheses $3 \mathrm{a}$ and $3 \mathrm{~b}$.

\subsection{Data}

For the empirical part of this analysis, we use data from a survey on the innovation activities of German enterprises called the "Mannheim Innovation Panel" (MIP). The survey is conducted annually by the Centre for European Economic Research (ZEW) on behalf of the German Federal Ministry of Education and Research ${ }^{1}$. The methodology and questionnaire used for the survey, which is targeted at enterprises with at least five employees, are harmonised with those used in the Community Innovation Survey (CIS), conducted every four years under the coordination of Eurostat. The method used for the German survey is stratified random sampling, with stratification by size, industry and region (eastern and western Germany). The questionnaire is based on the definitions and concepts of the OECD's "Oslo Manual". CIS surveys are self-reported and largely qualitative which raises quality issues with

\footnotetext{
${ }^{1}$ For a more detailed description of the MIP surveys, see Janz et al (2001). For sample sizes and weighted figures for a variety of topics related to the innovation behaviour of German firms in the 2003 MIP, see Rammer et al (2005).
} 
regard to administration, non-response and response accuracy (for a recent discussion, see Criscuolo et al, 2005). To tackle these quality issues, the following steps are taken: First, the CIS survey is administered via mail which prevents some of the shortcomings and biases of telephone interviews (for a discussion, see Bertrand and Mullainathan, 2001). The multinational application of CIS surveys adds extra layers of quality management and assurance. CIS surveys are subject to extensive pre-testing and piloting in various countries, industries and firms with regard to interpretability, reliability and validity (Laursen and Salter, 2006). Second, a comprehensive non-response analysis showed no systematic distortions between responding and non-responding firms with respect to their innovation activities. Third, the MIP questionnaire contains detailed definitions and examples to increase response accuracy. Longhand questions (eg "Please describe your most important product innovation briefly") allow robustness checks for multiple choice answers.

In conclusion, the major advantages of CIS surveys are that they provide direct, importanceweighted measures for a comprehensive set of sources (Criscuolo et al, 2005). Heads of R\&D departments or innovation managers are asked directly if and how they are able to generate innovations. This immediate information on processes and outputs can complement traditional measures for innovation such as patents (Grimpe and Sofka, 2008; Laursen and Salter, 2006). Our study represents such a case. The survey approach enables us to generate information on innovation projects that have not been started or were discarded. Moreover, it allows us to explore the reasons for this selection.

The survey in Germany is conducted annually but the precise formulation of questions varies. For consistency of questions, we use the surveys of 2005 and 2001 (as well as 1997 for lagged information). As a consequence, these two surveys cover half a decade of innovation activity. Each of these cross sections consists of about 5,000 observations. To achieve clarity in causal linkages, we use lagged values for investments in innovation activities. Each survey covers a three year reporting period which requires lagged information from the survey preceding it by 4 years. Hence, information is lagged from 2001 (for the survey of 2005) and 1997 (for the survey of 2001). While this approach enables us to clarify causality, it restricts our sample to firms that have consistently responded to the survey with a four year time lag in between. Moreover, we limit our database to firms with successful innovation activities (ie having generated new products, services or processes) because a number of variables is only available for them. Hence, we can only observe differences between innovative firms, which should be borne in mind when interpreting the results. Both measures limit the number of available observations. For the following descriptive and inferential analysis, we narrow the dataset to a balanced, pooled cross section data set of 758 observations.

\subsection{Variables}

\section{Dependent Variables}

According to Boyd et al (1993), a measure of the perceived importance of several possible factors is employed under uncertainty for project selection. Ideally, we would be able to trace each innovation project individually as well as the reasons for its rejection or cancellation. However, defining projects across firm and industry lines is difficult as hardly any objective 
criteria exist. What is more, rejected projects may not even be treated as projects if they are rejected in early phases of the innovation process, such as idea generation. Instead, we ask heads of R\&D departments and innovation management departments about their overall perception of why innovation projects were rejected or cancelled at their company. While exceptions to these general assessments may exist, we are confident that we can cover the overall selection criteria of management.

More precisely, respondents are requested to rate the importance of seven ${ }^{2}$ potential reasons for rejecting or cancelling projects on a 4-point Likert scale, ranging from "not relevant" to "high." The suggested items are:

- High economic risk

- High innovation costs

- Lack of external funding

- Organisational difficulties

- Lack of qualified personnel

- Lack of technological information

- Lack of market information

Obviously, these items are not independent of one another and it can be assumed that the heads of R\&D departments consider a combination of factors before deciding on the future of a project. We therefore conduct a principal component factor analysis to identify underlying patterns. The analysis goes well (Cronbach's alpha scale reliability coefficient: 0.81; KaiserMeyer-Olkin measure of sampling adequacy: 0.75) and we retain two factors with values of more than than 1. For content-related interpretation, we conduct an orthogonal varimax rotation. A likelihood ratio test confirms with an error probability of far below $1 \%$ that the two factors are independent, thus supporting the orthogonality assumption. (Kaiser and Rice, 1974). Factor loadings characterise individual factors distinctively (above 0.7), as illustrated in Figure 1.

2 The actual number of items varies among CIS surveys. Typically, the list is extended. These seven items are consistently available for the timeframe of our analysis. The 4-point Likert scale is also standardised by CIS. 


\section{Figure 1: Selection criteria - factor loadings after varimax rotation}

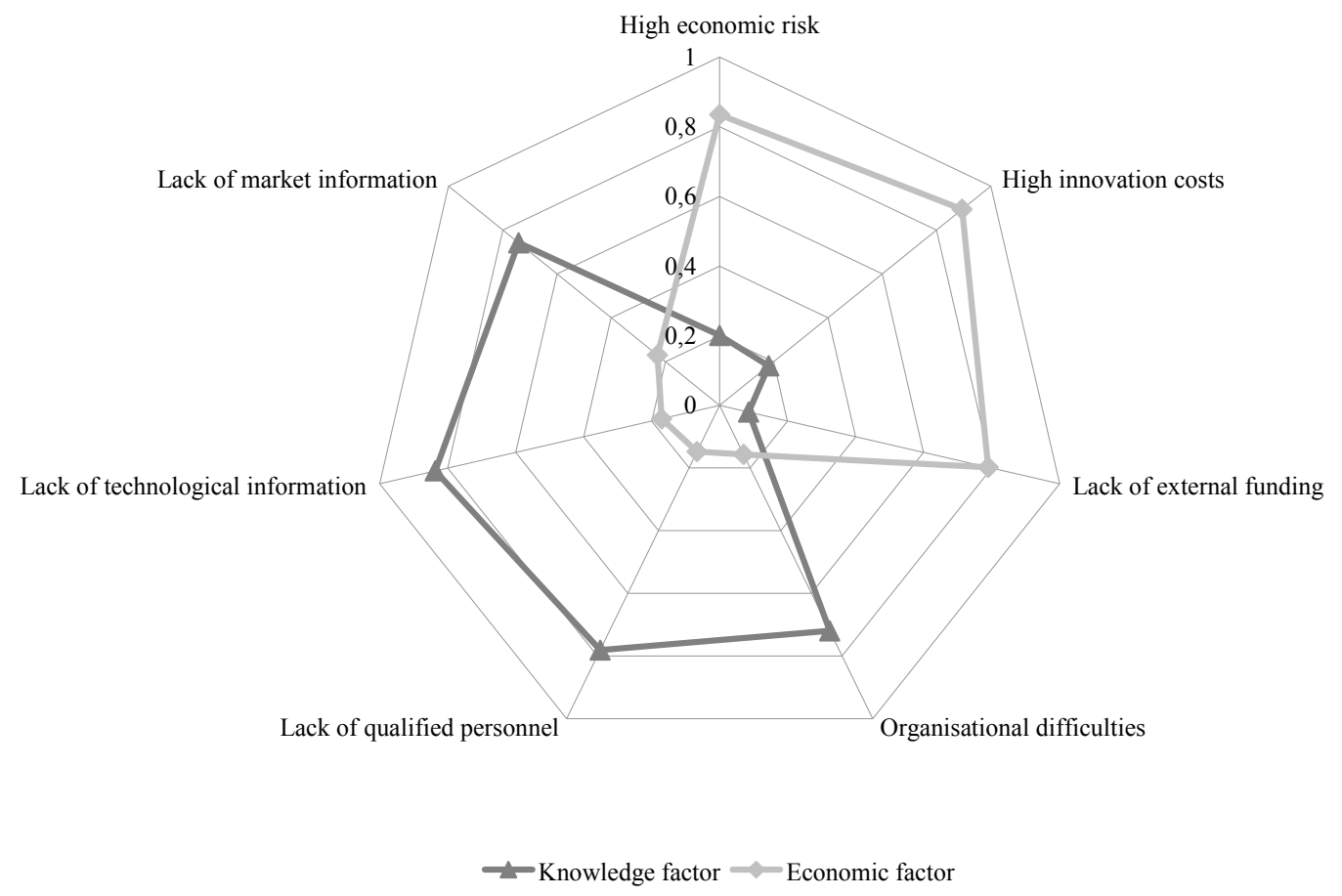

Hence, we retain two distinct factors through confirmatory factor analysis which reflect our conceptual distinction between economic and knowledge factors. Factor 1 is defined by economic reasoning (economic risks, costs, funding). We will therefore refer to it as the "economic factor" for project rejection or cancellation. Factor 2 is characterised by knowledge deficits. Interestingly, there is no distinction between market and technological information (both variables have an individual correlation coefficient of 0.69). These paucities in knowledge should typically relate to a shortage of qualified personnel as the carriers of knowledge or difficulties in organising them. As a result, we will subsequently refer to factor 2 as the "knowledge factor." We score both factors based on the results of the factor analysis and retain a scale which reflects the intensity of each factor for each firm (rescaled between zero and one).

We argue that the economic factor is closely related to the real options rationale laid out in Hypothesis 1. Selections based on economic risks, costs and financial sources would suggest reasoning based on financial considerations. The knowledge factor, though, is closer related to Hypothesis 2 which argues that previous innovation experience generates absorptive capacities that primarily translate into the ability to judge and acquire external knowledge. Hence, we use both factors as dependent variables in separate regression models to test our hypotheses. Factors are orthogonal to one another after varimax rotation, which makes ordinary least squares regressions most appropriate because no additional effects arise from formulating the estimation as a seemingly unrelated regression model.

\section{Independent variables of special interest}

Cohen and Levinthal (1989) suggest that absorptive capacities are developed by performing $R \& D$ and that $R \& D$ investment can therefore capture their extent. We use multiple variables 
to capture investments in absorptive capacities that are introduced to our structural model. First of all, the extent of investment in absorptive capacities is factored in as the sum of all innovation expenditure in a given year. As this variable is highly volatile, depending on the size of a firm, it is introduced in the empirical model as intensity, ie scaled by total sales. Absorptive capacity also depends on employees' skills (Cohen and Levinthal, 1990; Rothwell and Dodgson, 1991), which are taken into account by the share of employees with higher education in our empirical model. However, absorptive capacities may not just depend on investments in a single year but on their accumulation over time (Cohen and Levinthal, 1990). Hence, we introduce a dummy variable indicating whether R\&D activities are performed continuously over time. Additionally, innovation expenditure is broken down again into technological R\&D and non-R\&D innovation expenditure (eg investment in new machinery, market introduction and training related to innovation activities) as a share of sales in two additional regression models used to test our third hypothesis. Total sales figures and the different types of innovation expenditure for each firm, as well as the share of highly skilled employees, can be taken directly from questions in the questionnaire.

In order to bypass possible simultaneity issues (it is possible that, contrary to our line of argumentation in the previous sub-section, high perceived innovation barriers result in high innovation expenditure), we use the panel structure of our dataset and introduce all variables as lagged variables. Each survey requests information about innovation activities in the preceding three years. Innovation expenditure, however, is only available for the end of the three year reference period. Hence, we apply a time lag of four years to achieve clarity in causal linkages and take these data restrictions into account.

\section{Control variables}

In order to control for other factors possibly influencing the dependent variables, subsequent variables are introduced in the structural model. Firms of different sizes adopt different organisational structures. These varying mediating filters lead to different outcomes of information processing, and, as a result, different conclusions are reached in the selection process. This is incorporated in the structural model by entering the number of employees in logs. We also account for the fact that the firm has applied for patents or received public funding for its innovation projects through separate dummy variables. Both factors could influence a firm's uncertainty situation and therefore project selection. The effects of being part of a group, as well as a firm's degree of internationalisation are taken into account separately (factored in through the share of exports in total sales). Dummy variables indicating regional effects (whether the firm is located in eastern Germany), period effects and remaining industry effects complete the structural model. The incorporated industry dummies take account of medium high-tech manufacturing, high-tech manufacturing, distributive, knowledge-intensive and technological services. The other manufacturing sector is the reference group. The Appendix provides a detailed industry classification.

\section{Descriptive statistics}

In table 1, we present some descriptive statistics for our sample. In order to identify differences between firms with high respective values for knowledge and economic factors and those with low values, we present descriptive statistics for firms with different values for 
knowledge and economic factors. A straightforward way to group the firms is to use the median of the knowledge factor $(0.353)$ and that of the economic factor $(0.601)^{3}$ as the dividing line.

The firms with high values for the respective factors are quite different to those with low values along several dimensions. With respect to the knowledge factors, most of the differences are due to factors that are not directly related to the innovation activities of firms. Firms with a high value for knowledge factors are more often located in western Germany and are on average larger than firms with low values for the knowledge factor. They also have a significantly higher share of exports in sales and are less likely to be in the distributive services or knowledge-intensive services industry. Some innovation activity indicators also differ significantly between firms with a high knowledge factor and those with low one. A larger share $(66 \%)$ of the former are involved in continuous $R \& D$ activities than the latter $(58 \%)$. For the group of firms with high values for the knowledge factor, we also find a higher share of firms assigning crucial importance to suppliers as a source of information than for those with lower values. Similarly, the share of firms applying for patent protection for their innovations is higher for the first group than for the second. In contrast, the share of firms that receive public funding is higher in the group of firms with knowledge factors below the median.

The differences between firms with an above-median economic factor value and those with a sub-median economic factor value are even more pronounced than the knowledge factor split. One thing that sticks out is the difference with respect to the innovation intensity. Firms with above-median values for the economic factor spend a larger share of their turnover on innovation activities (both $R \& D$ and non-R\&D) than the other half of the sample. They also have a larger share of employees with a university degree. The economic factor seems to be more important for firms with continuous $R \& D$ activities and those receiving public funding.

Similar to the results for the knowledge factors, the firms forming the two groups of economic factor values differ with respect to more general firm characteristics like location in eastern Germany, share of exports in sales and size. The structure is reversed, however. While firms with high knowledge factor values are on average larger than their peers, firms with high economic factor values are on average smaller than firms with low values. Similarly, the share of eastern German firms is higher in the above-median group here, whereas it is lower for the high knowledge factor value group. The share of exports is lower for the sub-median group than for the above-median group when looking at the economic factors, and higher when looking at the knowledge factor group.

The descriptive statistics indicate that institutional and environmental factors along with innovation-related activities influence the type of strategy a firm uses for evaluating potential projects. Institutional and environmental factors (eg size, location, exports) seem to be related to the choice or preference for one of the two methods of evaluating projects.

\footnotetext{
${ }^{3}$ The firms on the median are included in the group labelled "above median"
} 
Table 1: $\quad$ Descriptive statistics

\begin{tabular}{|c|c|c|c|c|c|c|c|c|c|}
\hline \multirow[b]{2}{*}{ Variable } & \multicolumn{2}{|c|}{$\begin{array}{l}\text { Knowledge } \\
\text { factor above } \\
\text { median }\end{array}$} & \multicolumn{2}{|c|}{$\begin{array}{l}\text { Knowledge } \\
\text { factor below } \\
\text { median }\end{array}$} & & \multicolumn{2}{|c|}{$\begin{array}{l}\text { Economic factor } \\
\underline{\text { above median }}\end{array}$} & \multicolumn{2}{|c|}{$\begin{array}{l}\text { Economic } \\
\text { factor below } \\
\text { median }\end{array}$} \\
\hline & Mean & $\begin{array}{l}\text { Std } \\
\text { dev }\end{array}$ & Mean & $\begin{array}{l}\text { Std } \\
\text { dev }\end{array}$ & & Mean & $\begin{array}{l}\text { Std } \\
\text { dev }\end{array}$ & Mean & $\begin{array}{l}\text { Std } \\
\text { dev }\end{array}$ \\
\hline $\begin{array}{l}\text { Innovation expenditure as share } \\
\text { of sales ( } t-1)\end{array}$ & 0.063 & 0.090 & 0.062 & 0.095 & & 0.077 & 0.114 & 0.048 & 0.063 \\
\hline $\begin{array}{l}\text { Non-R\&D expenditure as share } \\
\text { of sales }(t-1)\end{array}$ & 0.033 & 0.060 & 0.035 & 0.068 & & 0.041 & 0.080 & 0.026 & 0.042 \\
\hline $\begin{array}{l}\text { R\&D expenditure as share of } \\
\text { sales }(t-1)\end{array}$ & 0.030 & 0.060 & 0.063 & 0.097 & & 0.035 & 0.072 & 0.022 & 0.044 \\
\hline Continuous R\&D activity (t-1) & 0.641 & 0.480 & 0.564 & 0.497 & $\mathrm{~b}$ & 0.640 & 0.481 & 0.565 & 0.496 \\
\hline $\begin{array}{l}\text { Share of employees with } \\
\text { university degree }(\mathrm{t}-1)\end{array}$ & 18.19 & 20.07 & 20.74 & 22.87 & & 22.03 & 23.25 & 16.83 & 19.30 \\
\hline $\begin{array}{l}\text { Customers as crucial } \\
\text { information source }(\mathrm{t}-1)\end{array}$ & 0.204 & 0.403 & 0.225 & 0.418 & & 0.231 & 0.422 & 0.198 & 0.399 \\
\hline $\begin{array}{l}\text { Suppliers as crucial information } \\
\text { source }(\mathrm{t}-1)\end{array}$ & 0.181 & 0.385 & 0.114 & 0.318 & $\mathrm{~b}$ & 0.164 & 0.371 & 0.130 & 0.337 \\
\hline $\begin{array}{l}\text { Competitors as crucial } \\
\text { information source }(\mathrm{t}-1)\end{array}$ & 0.038 & 0.191 & 0.023 & 0.151 & & 0.035 & 0.183 & 0.027 & 0.161 \\
\hline $\begin{array}{l}\text { Research facilities as crucial } \\
\text { information source }(\mathrm{t}-1)\end{array}$ & 0.096 & 0.295 & 0.094 & 0.292 & & 0.124 & 0.330 & 0.065 & 0.247 \\
\hline Patent protection & 0.356 & 0.479 & 0.292 & 0.456 & $\mathrm{c}$ & 0.303 & 0.460 & 0.346 & 0.476 \\
\hline Public funding & 0.242 & 0.430 & 0.339 & 0.474 & $\mathrm{c}$ & 0.357 & 0.480 & 0.222 & 0.416 \\
\hline Part of conglomerate & 0.510 & 0.501 & 0.459 & 0.499 & & 0.484 & 0.500 & 0.485 & 0.501 \\
\hline Location in eastern Germany & 0.294 & 0.456 & 0.444 & 0.498 & $\mathrm{a}$ & 0.403 & 0.491 & 0.334 & 0.472 \\
\hline Share of exports of sales & 0.219 & 0.253 & 0.175 & 0.239 & $\mathrm{~b}$ & 0.170 & 0.226 & 0.225 & 0.264 \\
\hline No of employees (logs) & 4.586 & 1.392 & 4.171 & 1.491 & $\mathrm{a}$ & 4.210 & 1.461 & 4.553 & 1.432 \\
\hline Year 2005 & 0.437 & 0.497 & 0.608 & 0.489 & $\mathrm{a}$ & 0.519 & 0.500 & 0.527 & 0.500 \\
\hline Medium high-tech manuf & 0.220 & 0.414 & 0.208 & 0.406 & & 0.190 & 0.393 & 0.237 & 0.426 \\
\hline High-tech manufacturing & 0.082 & 0.274 & 0.064 & 0.247 & & 0.086 & 0.281 & 0.059 & 0.236 \\
\hline Distributive services & 0.096 & 0.295 & 0.152 & 0.360 & $\mathrm{~b}$ & 0.107 & 0.309 & 0.142 & 0.350 \\
\hline Knowledge-intensive services & 0.044 & 0.205 & 0.070 & 0.256 & & 0.058 & 0.233 & 0.056 & 0.231 \\
\hline Technological services & 0.099 & 0.299 & 0.120 & 0.325 & & 0.130 & 0.336 & 0.089 & 0.285 \\
\hline Knowledge factor & 0.497 & 0.120 & 0.199 & 0.092 & $\mathrm{a}$ & 0.347 & 0.181 & 0.348 & 0.186 \\
\hline Economic factor & 0.590 & 0.189 & 0.565 & 0.255 & & 0.761 & 0.105 & 0.389 & 0.144 \\
\hline No of observations & & & & & & & & & \\
\hline
\end{tabular}

Notes: $\mathrm{a}, \mathrm{b}$ and $\mathrm{c}$ indicate significant differences of $1 \%, 5 \%$ and $10 \%$, respectively, in means of the belowmedian and above-median subsamples; the "above-median" group includes the median firms. In the case of the knowledge factors, there are 12 median firms, for economic factors 8 .

\subsection{Empirical model and method}

We perform ordinary least-squares regression analyses to test the hypotheses. The formal model to test hypotheses 1 and 2 consists of the two following equations which are calculated independently of each other by means of OLS regressions: 


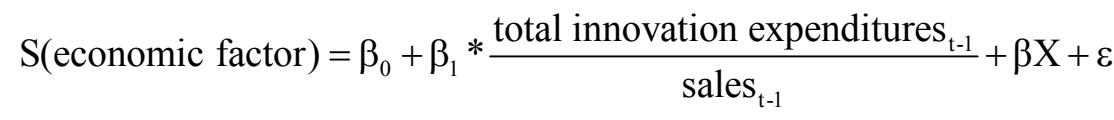

$\mathrm{S}($ knowledge factor $)=\alpha_{0}+\alpha_{1} * \frac{\text { total innovation expenditures }}{\mathrm{t}-1}+\alpha \mathrm{X}+\eta$

$\mathrm{S}$ (economic factor) is the scale that measures the importance of economic feasibility as a reason for firms abandoning or not starting innovation projects and $\mathrm{S}$ (knowledge factor) is the corresponding scale for the importance of knowledge deficits. $\mathrm{X}$ is the vector of control variables and $\varepsilon, \eta$ are stochastic error terms. In order to be able to test our third hypothesis, we split up total innovation expenditure into $R \& D$ and non-R\&D innovation expenditure. With this modification, the two equations that make up the formal model for the third hypothesis are as follows.

$$
\begin{aligned}
& \mathrm{S}(\text { economic factor })=\gamma_{0}+\gamma_{1} * \frac{\text { R\&D expenditures }_{\mathrm{t}-1}}{\text { sales }_{\mathrm{t}-1}}+\gamma_{2} * \frac{\text { non-R\&D expenditures }_{\mathrm{t}-1}}{\text { sales }_{\mathrm{t}-1}}+\gamma \mathrm{X}+\varepsilon \\
& \mathrm{S}(\text { knowledge factor })=\delta_{0}+\delta_{1} * \frac{\text { R\&D expenditures }_{\mathrm{t}-1}}{\text { sales }_{\mathrm{t}-1}}+\delta_{2} * \frac{\text { non-R\&D expenditures }_{\mathrm{t}-1}}{\text { sales }_{\mathrm{t}-1}}+\delta \mathrm{X}+\eta
\end{aligned}
$$




\section{$5 \quad$ Results}

The results of our least-squares estimation for the full sample of 685 firms are presented in Table 2 for Model I and Table 3 for Model II. The two equations for Model I contain total innovation expenditure as a share of sales in the preceding reporting period and factor in previous innovation experience. For the two equations in Model II, total innovation expenditure is split into two distinct categories - R\&D expenditure and later-stage, non-R\&D innovation expenditure.

Table 2: $\quad$ Results of ordinary least-squares regression analysis on Model I (total innovation expenditure)

\begin{tabular}{|c|c|c|c|c|}
\hline \multirow{2}{*}{ Model I } & \multicolumn{2}{|c|}{ Economic factor } & \multicolumn{2}{|c|}{ Knowledge factor } \\
\hline & Coef & Std err & Coef & Std. err \\
\hline Innovation expenditure as share of sales $(\mathrm{t}-1)$ & $0.236^{* * *}$ & 0.077 & 0.107 & 0.082 \\
\hline \multicolumn{5}{|l|}{ Non-R\&D expenditure as share of sale (t-1) } \\
\hline \multicolumn{5}{|l|}{ R\&D expenditure as share of sales (t-1) } \\
\hline Continuous R\&D activity (t-1) ${ }^{\dagger}$ & $0.053 * * *$ & 0.021 & 0.026 & 0.017 \\
\hline Share of employees with university degree $(\mathrm{t}-1)^{\dagger}$ & 0.000 & 0.001 & -0.000 & 0.000 \\
\hline Part of company group ${ }^{\dagger}$ & 0.008 & 0.018 & 0.014 & 0.015 \\
\hline Location in eastern Germany ${ }^{\dagger}$ & $-0.036^{*}$ & 0.020 & $-0.052 * * *$ & 0.016 \\
\hline Share of exports in sales & $-0.120 * * *$ & 0.041 & -0.013 & 0.035 \\
\hline No of employees (logs) & $-0.017 * *$ & 0.008 & $0.013 * *$ & 0.006 \\
\hline Public funding for $\mathrm{R} \& \mathrm{D}^{\dagger}$ & $0.068 * * *$ & 0.021 & $-0.048 * * *$ & 0.018 \\
\hline Patent protection ${ }^{\dagger}$ & -0.022 & 0.022 & 0.007 & 0.018 \\
\hline Year $2005^{\dagger}$ & -0.021 & 0.018 & $-0.067 * * *$ & 0.014 \\
\hline Medium high-tech manufacturing $^{\dagger}$ & 0.002 & 0.025 & -0.006 & 0.020 \\
\hline High-tech manufacturing $^{\dagger}$ & 0.009 & 0.038 & 0.003 & 0.029 \\
\hline Distributive services $^{\dagger}$ & -0.036 & 0.029 & -0.023 & 0.023 \\
\hline Knowledge-intensive services ${ }^{\dagger}$ & 0.006 & 0.04 & -0.032 & 0.033 \\
\hline Technological services ${ }^{\dagger}$ & -0.033 & 0.038 & 0.011 & 0.032 \\
\hline Constant & $0.637 * * *$ & 0.038 & $0.336^{* * *}$ & 0.031 \\
\hline Number of observations & & 685 & & 685 \\
\hline $\mathrm{F}$ & $(15,669)$ & 4.81 & $(15,669)$ & 5.93 \\
\hline Prob $>$ F & & 0.00 & & 0.00 \\
\hline $\mathrm{R}^{2}$ & & 0.08 & & 0.10 \\
\hline Root MSE & & 0.22 & & 0.18 \\
\hline
\end{tabular}

$* * *, * * *$ indicate significance of $1 \%, 5 \%$ or $10 \%$; robust standard errors; $\uparrow$ indicate a dummy variable

The regression results for Model I support hypothesis 1 and reject hypothesis 2. Experience from previous innovation expenditure has a positive and significant impact on project selection based on economic factors. Performing R\&D continuously has an additive effect. However, there is no such effect on the knowledge factor. The effect takes hold once we split innovation expenditure into $\mathrm{R} \& \mathrm{D}$ and later-stage innovation expenditure (Model II). As suggested in hypothesis $3 \mathrm{a}$, the former represents $\mathrm{R} \& \mathrm{D}$ experience reflected in subsequent, knowledge-based selection while the latter generates market experience that is reflected in 
economic project selection as suggested in hypothesis $3 \mathrm{~b}$. Interestingly, continuous $\mathrm{R} \& \mathrm{D}$ activities still only propel economic project selection.

Two major patterns emerge from our results. First, total innovation expenditure, ie the sum of $R \& D$ expenditure and non-R\&D expenditure as a share in total sales does not significantly affect the evaluation of projects based on knowledge factors. However, firms with high R\&D expenditure in the past select projects based on these criteria (see table 3). Interestingly, the knowledge-based selection does not depend on continuous R\&D engagements. Apparently, selecting projects based on knowledge criteria requires established technological knowledge stocks which are developed in-house.

Second, non-R\&D, later-stage innovation expenditure is reflected in project selection based on economic factors. Non-R\&D innovation expenditure includes preparation for the market introduction of new products, acquisition of production machinery and existing, external knowledge such as licenses. Firms that spend a large part of their turnover on these types of activities are more likely to evaluate innovation projects based on economic criteria and commercialisation prospects than firms that spend less on non-R\&D innovation. They are in a better position to assess costs and risks. This experience seems to help them to evaluate the economic value of future innovation projects. Accumulation and centralisation of these experiences through continuous $R \& D$ engagements, which are often associated with having a dedicated department, propel decision-making based on economic factors. 
Table 3: $\quad$ Results of ordinary least-squares regression analysis on Model II (R\&D and non-R\&D innovation expenditure)

\begin{tabular}{|c|c|c|c|c|}
\hline \multirow[t]{2}{*}{ Model II } & \multicolumn{2}{|c|}{ Economic factor } & \multicolumn{2}{|c|}{ Knowledge factor } \\
\hline & Coef & Std err & Coef & Std err \\
\hline \multicolumn{5}{|l|}{ Innovation expenditure as share of sales ( $(-1)$} \\
\hline Non-R\&D expenditure as share of sale $(\mathrm{t}-1)$ & $0.289 * * *$ & 0.097 & 0.028 & 0.12 \\
\hline$R \& D$ expenditure as share of sales (t-1) & 0.154 & 0.142 & $0.229 * *$ & 0.109 \\
\hline Continuous R\&D activity $(\mathrm{t}-1)^{\dagger}$ & $0.054 * * *$ & 0.021 & 0.025 & 0.017 \\
\hline Share of employees with university degree $(\mathrm{t}-1)^{\dagger}$ & 0.000 & 0.001 & -0.000 & 0.000 \\
\hline Part of company group ${ }^{\dagger}$ & 0.007 & 0.018 & 0.015 & 0.015 \\
\hline Location in eastern Germany ${ }^{\dagger}$ & $-0.037^{*}$ & 0.020 & $-0.051 * * *$ & 0.016 \\
\hline Share of exports in sales & $-0.119 * * *$ & 0.041 & -0.015 & 0.035 \\
\hline No of employees $(\operatorname{logs})$ & $-0.018 * *$ & 0.008 & $0.013^{* *}$ & 0.006 \\
\hline Public funding for $\mathrm{R} \& \mathrm{D}^{\dagger}$ & $0.070 * * *$ & 0.021 & $-0.050 * * *$ & 0.018 \\
\hline Patent protection ${ }^{\dagger}$ & -0.020 & 0.023 & 0.004 & 0.019 \\
\hline Year $2005^{\dagger}$ & -0.020 & 0.018 & $-0.069 * * *$ & 0.014 \\
\hline Medium high-tech manufacturing ${ }^{\dagger}$ & 0.002 & 0.025 & -0.006 & 0.020 \\
\hline High-tech manufacturing ${ }^{\dagger}$ & 0.012 & 0.038 & -0.001 & 0.029 \\
\hline Distributive services $^{\dagger}$ & -0.035 & 0.029 & -0.024 & 0.023 \\
\hline Knowledge-intensive services ${ }^{\dagger}$ & 0.007 & 0.040 & -0.033 & 0.033 \\
\hline Technological services $^{\dagger}$ & -0.032 & 0.038 & 0.010 & 0.032 \\
\hline Constant & $0.635^{* * *}$ & 0.038 & $0.340^{* * *}$ & 0.031 \\
\hline Number of observations & & 685 & & 685 \\
\hline $\mathrm{F}$ & $(16,668)$ & 4.54 & $(16,668)$ & 5.55 \\
\hline Prob $>$ F & & 0.00 & & 0.00 \\
\hline $\mathrm{R}^{2}$ & & 0.08 & & 0.10 \\
\hline Root MSE & & 0.22 & & 0.18 \\
\hline
\end{tabular}

$* * *, * *, *$ indicate significance of $1 \%, 5 \%$ or $10 \%$; robust standard errors; $\uparrow$ indicate a dummy variable

We do not develop a priori hypothesis for control variables. Nevertheless, their estimated results are discussed briefly. The significant results for all variables remain stable for both Model I and Model II. With regard to project selection based on economic factors, we find that internationalisation has negative effects. The latter is typically associated with a firm's growth strategies. As firms venture out of their home market environment, they experience certain unavoidable extra costs stemming from spatial distance (eg transportation, time zones), a lack of reputation and roots in the host market as well as possible export restrictions in the home market (Zaheer, 1995). These additional costs may be justified by realised or expected revenue increases from new markets and are therefore easier to accept in the project selection stage. The size of a firm, based on the number of employees, has a positive effect on the importance the firm attributes to knowledge-related factors when selecting innovation projects. In contrast, economic criteria in project selection are less important for large firms compared to small ones. We find the opposite effect for the knowledge factor. This may reflect the overall resource limitations of small firms and the resulting need to closely monitor economic factors. The same may be true for the recipients of public funding for their R\&D activities. However, this resource limitation effect appears to have no additional regional dimension. Firms located in the economically challenged eastern part of Germany place significantly less importance on both economic and knowledge factors in selecting innovation 
projects compared to their western German counterparts. We find no evidence of additional industry effects.

\section{Consistency check}

We conduct an additional consistency check. Given the close relationship between investments in innovation activities and the establishment of absorptive capacities, it is difficult to distinguish between the two "faces" of R\&D (Cohen and Levinthal, 1989), which is nevertheless relevant for our theoretical discussion because we base some of the discussion on this stream of literature. We address this issue in a separate regression model by distinguishing between the potential absorptive capacity and its actual usage, ie for the identification, assimilation and exploitation of external knowledge. The existing literature refers to these two stages as potential vs realised absorptive capacity (Jansen et al, 2005; Zahra and George, 2002). The latter is accounted for by dummy variables indicating whether the firm was actually able to rely strongly ${ }^{4}$ on external information sources and turn them into successful innovations. As suggested by Frost et al (2002), we cover four important sources: customers, suppliers, competitors and research institutions (universities). ${ }^{5} \mathrm{We}$ find almost no significant support for the importance of realised absorptive capacity. All main effects remain stable. Full regression results are provided in Appendix D.

$4 \quad$ Firms were asked to rate the importance of external knowledge sources for successful innovation separately on a 4-point Likert scale ("not relevant" to "high"). The dummy variables are 1 if the firm indicated that the importance was high.

5 Adding interaction effects between innovation expenditure and external innovation sources to the econometric model provided no additional, significant insights. Existing main effects remain stable. 


\section{Discussion}

We are conducting this study to obtain a better understanding of the learning effects from innovation engagements. More precisely, we ask: What does previous innovation experience tell firms about what not to do in the future? With that in mind, we focus on projects that did not materialise or were abandoned - an important building block for choosing and implementing the "right" projects. We suggest two major learning mechanisms to help firms to deal with the inherent uncertainty of innovation projects that forces them to build project portfolios and weed out the least promising. On the one hand, real options theory suggests a process based on financial data and that firms with previous experience in conducting innovation projects are better able to judge necessary funds, costs and risks. On the other hand, research on absorptive capacities finds that previous innovation experience translates into superior capabilities to value, extract and exploit external knowledge. We test both hypotheses empirically for a large dataset of German firms and over long periods of time.

Our results indicate congruence between the firms' innovation experience and their project selection patterns in the future. Extensive R\&D experience materialises as knowledge stocks that enable firms to judge projects based on knowledge criteria. Non-R\&D experience, however, stemming from producing and introducing products to markets, resonates as decision-making based on economic factors in the future. Both stages of innovation activities appear to generate distinct decision-making capabilities inside the firm which are subsequently exploited in selecting projects for the future.

Furthermore, our findings on the effects of continuous $R \& D$ engagements on project selection in the future may provide additional insights into how firms learn from R\&D. We find that accumulating knowledge over time (ie conducting in-house R\&D continuously) leads to project selection based on economic factors. This indicates that the value of R\&D, though often associated with having a dedicated department as the nexus of a firm's innovation activities, may not exclusively stem from knowledge retention and build-up. Equally important could be its role in re-evaluating existing knowledge after it has been market-tested and injecting this economic assessment of knowledge back into the innovation process. Furthermore, those firms continuously involved in in-house R\&D will be better able to assess the real costs of a project and its market prospects vis-à-vis the innovation activities of their competitors.

Important lessons can be drawn from our findings for both management and policy recommendations if the aim is to influence a firm's project portfolios. For the former, this may imply a change in strategy while the latter may be interested in steering economic activities in new directions. We find that the type of previous innovation experience significantly influences portfolio management in the future. Firms may be led (through management) or lured (through policy instruments) in new directions. But this process is risky as firms will become less adept to judge projects outside of their established field of experience. Thus, a more long-term-oriented policy approach may be a more promising mechanism for changing a firm's selection pattern. 


\section{$7 \quad$ Caveats and future research}

Our analysis has some limitations which may provide opportunities for future research. First, our empirical results are limited to the German context. It would be interesting to see comparative studies from other countries, especially from developing economies. Secondly, we benefit from an established survey with extensive coverage and quality management. However, the list of potential criteria for project selection is not exhaustive and somewhat driven by existing, available data. Dedicated surveys may provide additional insights. Finally, rejecting or cancelling a project may only be one basic element of a broad variety of management options. Firms may opt for deferring, recombining or reconfiguring existing projects which may also imply outsourcing them. A better understanding of these patterns and the effects of previous experience on their usage would certainly be a fruitful road for further academic investigation. 


\section{$8 \quad$ Appendix}

\section{Appendix A: Industry breakdown}

\begin{tabular}{lll}
\hline \hline Industry Group & NACE Code & Industry Group \\
\hline Food and tobacco & $15-16$ & Other manufacturing \\
Textiles and leather & $17-19$ & Other manufacturing \\
Wood/paper/publishing & $20-22$ & Other manufacturing \\
Chemicals/petroleum & $23-24$ & Medium high-tech manufacturing \\
Plastics/rubber & 25 & Other manufacturing \\
Glass/ceramics & 26 & Other manufacturing \\
Metal & $27-28$ & Other manufacturing \\
Manufacture of machinery and equipment & 29 & Medium high-tech manufacturing \\
Manufacture of electrical equipment and & $30-32$ & High-tech manufacturing \\
electronics & & \\
Medical, precision and optical instruments & 33 & High-tech manufacturing \\
Manufacture of motor vehicles & $34-35$ & Medium high-tech manufacturing \\
Manufacture of furniture, jewellery, sports & $36-37$ & Other manufacturing \\
equipment and toys & & \\
Electricity, gas and water supply & $40-41$ & Other manufacturing \\
Construction & 45 & Other manufacturing \\
Retail and motor trade & 50,52 & Distributive services \\
Wholesale trade & 51 & Distributive services \\
Transportation and communication & $60-63,64.1$ & Distributive services \\
Financial intermediation & $65-67$ & Knowledge-intensive services \\
Real estate activities and renting & $70-71$ & Distributive services \\
ICT services & $72,64.3$ & Technological services \\
Technical services & $73,74.2,74.3$ & Technological services \\
Consulting & $74.1,74.4$ & Knowledge-intensive services \\
Motion picture/broadcasting & $92.1-92.2$ & Knowledge-intensive services \\
Other business-oriented services & $74.5-74.8,90$ & Distributive services \\
\hline \hline
\end{tabular}




\section{Appendix B: Descriptive statistics}

\begin{tabular}{|c|c|c|c|c|c|c|c|c|c|c|c|c|}
\hline \multirow[b]{2}{*}{ Variable } & \multicolumn{2}{|c|}{ Whole sample } & \multicolumn{2}{|c|}{$\begin{array}{l}\text { Knowledge } \\
\text { factor above } \\
\text { median }\end{array}$} & \multicolumn{3}{|c|}{$\begin{array}{l}\text { Knowledge } \\
\text { factor below } \\
\text { median }\end{array}$} & \multicolumn{2}{|c|}{$\begin{array}{l}\text { Economic factor } \\
\text { above median }\end{array}$} & \multicolumn{3}{|c|}{$\begin{array}{l}\text { Economic } \\
\text { factor below } \\
\text { median }\end{array}$} \\
\hline & Mean & $\begin{array}{l}\text { Std } \\
\text { dev }\end{array}$ & Mean & $\begin{array}{l}\text { Std } \\
\text { dev }\end{array}$ & Mean & $\begin{array}{l}\text { Std } \\
\text { dev }\end{array}$ & & Mean & $\begin{array}{l}\text { Std } \\
\text { dev }\end{array}$ & Mean & $\begin{array}{l}\text { Stdd } \\
\text { dev }\end{array}$ & \\
\hline $\begin{array}{l}\text { Innovation } \\
\text { expenditure } \\
\text { as share of } \\
\text { sales (t-1) }\end{array}$ & 0.062 & 0.094 & 0.063 & 0.090 & 0.062 & 0.095 & & 0.077 & 0.114 & 0.048 & 0.063 & $\mathrm{c}$ \\
\hline $\begin{array}{l}\text { Non-R\&D } \\
\text { expenditure } \\
\text { as share of } \\
\text { sales (t-1) }\end{array}$ & 0.034 & 0.064 & 0.033 & 0.060 & 0.035 & 0.068 & & 0.041 & 0.080 & 0.026 & 0.042 & $\mathrm{c}$ \\
\hline $\begin{array}{l}\text { R\&D } \\
\text { expenditure } \\
\text { as share of } \\
\text { sales (t-1) }\end{array}$ & 0.029 & 0.060 & 0.030 & 0.060 & 0.063 & 0.097 & $\mathrm{c}$ & 0.035 & 0.072 & 0.022 & 0.044 & $\mathrm{c}$ \\
\hline $\begin{array}{l}\text { Continuous } \\
\text { R\&D activity } \\
(\mathrm{t}-1)\end{array}$ & 0.603 & 0.490 & 0.641 & 0.480 & 0.564 & 0.497 & $\mathrm{c}$ & 0.640 & 0.481 & 0.565 & 0.496 & $\mathrm{c}$ \\
\hline $\begin{array}{l}\text { Share of } \\
\text { employees } \\
\text { with } \\
\text { university } \\
\text { degree (t-1) }\end{array}$ & 19.47 & 21.53 & 18.19 & 20.07 & 20.74 & 22.87 & $\mathrm{c}$ & 22.03 & 23.25 & 16.83 & 19.30 & $\mathrm{c}$ \\
\hline $\begin{array}{l}\text { Customers as } \\
\text { crucial } \\
\text { information } \\
\text { source (t-1) }\end{array}$ & 0.215 & 0.411 & 0.204 & 0.403 & 0.225 & 0.418 & & 0.231 & 0.422 & 0.198 & 0.399 & \\
\hline $\begin{array}{l}\text { Suppliers as } \\
\text { crucial } \\
\text { information } \\
\text { source }(\mathrm{t}-1)\end{array}$ & 0.147 & 0.355 & 0.181 & 0.385 & 0.114 & 0.318 & $\mathrm{c}$ & 0.164 & 0.371 & 0.130 & 0.337 & \\
\hline $\begin{array}{l}\text { Competitors } \\
\text { as crucial } \\
\text { information } \\
\text { source }(\mathrm{t}-1)\end{array}$ & 0.031 & 0.173 & 0.038 & 0.191 & 0.023 & 0.151 & & 0.035 & 0.183 & 0.027 & 0.161 & \\
\hline $\begin{array}{l}\text { Research } \\
\text { facilities as } \\
\text { crucial } \\
\text { information } \\
\text { source }(\mathrm{t}-1)\end{array}$ & 0.095 & 0.293 & 0.096 & 0.295 & 0.094 & 0.292 & & 0.124 & 0.330 & 0.065 & 0.247 & $\mathrm{c}$ \\
\hline $\begin{array}{l}\text { Part of } \\
\text { conglomerate }\end{array}$ & 0.485 & 0.500 & 0.510 & 0.501 & 0.459 & 0.499 & $\mathrm{a}$ & 0.484 & 0.500 & 0.485 & 0.501 & \\
\hline $\begin{array}{l}\text { Location in } \\
\text { eastern } \\
\text { Germany }\end{array}$ & 0.369 & 0.483 & 0.294 & 0.456 & 0.444 & 0.498 & $\mathrm{c}$ & 0.403 & 0.491 & 0.334 & 0.472 & $\mathrm{c}$ \\
\hline $\begin{array}{l}\text { Share of } \\
\text { exports of } \\
\text { sales }\end{array}$ & 0.197 & 0.247 & 0.219 & 0.253 & 0.175 & 0.239 & $\mathrm{c}$ & 0.170 & 0.226 & 0.225 & 0.264 & $\mathrm{c}$ \\
\hline $\begin{array}{l}\text { No of } \\
\text { employees } \\
(\operatorname{logs})\end{array}$ & 4.380 & 1.456 & 4.586 & 1.392 & 4.171 & 1.491 & $\mathrm{c}$ & 4.210 & 1.461 & 4.553 & 1.432 & $\mathrm{c}$ \\
\hline $\begin{array}{l}\text { Public } \\
\text { funding }\end{array}$ & 0.291 & 0.454 & 0.242 & 0.430 & 0.339 & 0.474 & $\mathrm{c}$ & 0.357 & 0.480 & 0.222 & 0.416 & $\mathrm{c}$ \\
\hline $\begin{array}{l}\text { Patent } \\
\text { protection }\end{array}$ & 0.324 & 0.468 & 0.356 & 0.479 & 0.292 & 0.456 & $\mathrm{c}$ & 0.303 & 0.460 & 0.346 & 0.476 & $\mathrm{a}$ \\
\hline Year 2005 & 0.523 & 0.500 & 0.437 & 0.497 & 0.608 & 0.489 & $\mathrm{c}$ & 0.519 & 0.500 & 0.527 & 0.500 & \\
\hline
\end{tabular}




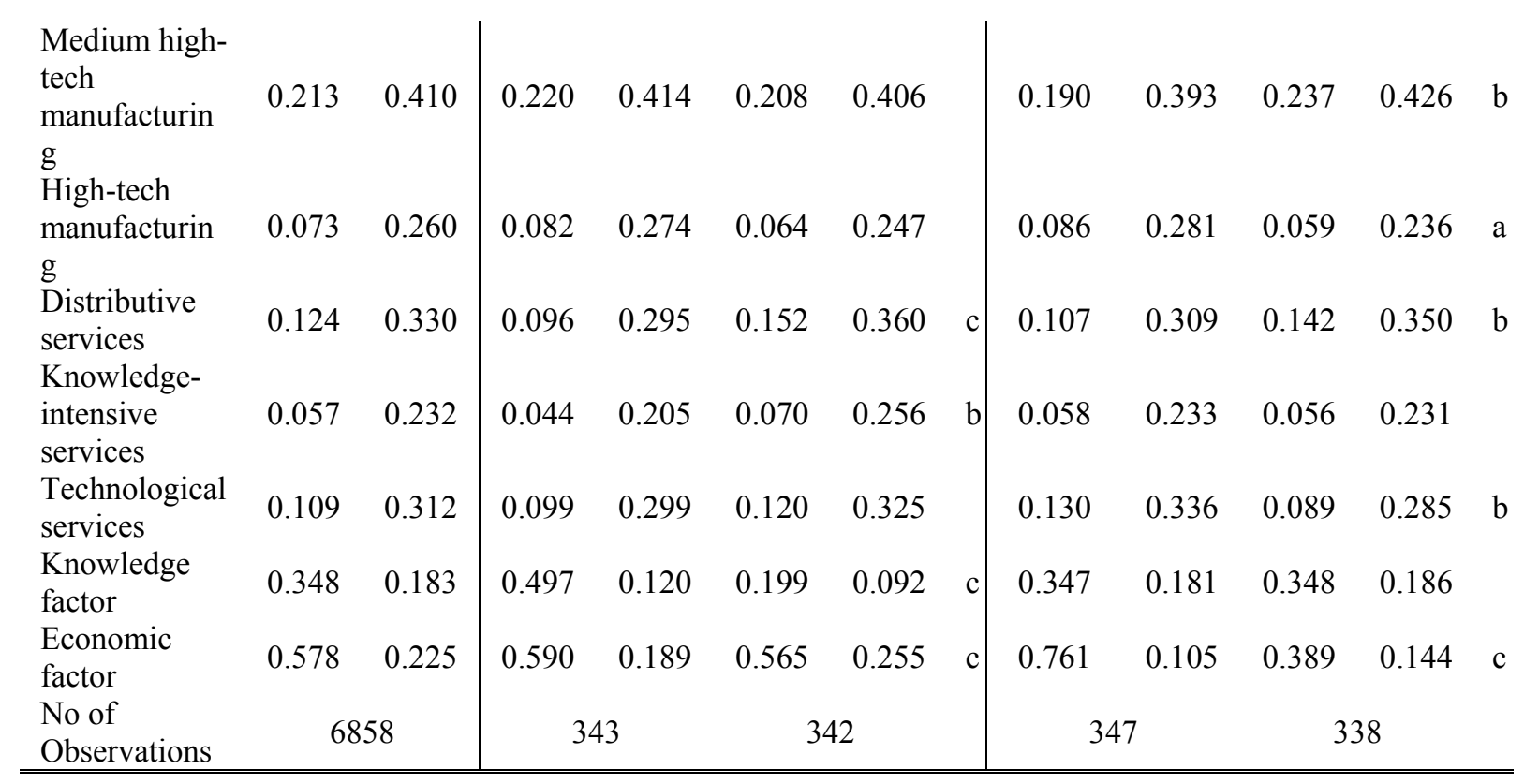

Notes: $\mathrm{a}, \mathrm{b}$ and $\mathrm{c}$ indicate significant differences of $1 \%, 5 \%$ and $10 \%$, respectively, in means of the belowmedian and above-median subsamples; the "abovemedian" group includes the median firms. In the case of the knowledge factors, there are 12 median firms, for economic factors 8 . 


\section{Appendix C: Correlation matrix and variance inflation factors of the regressors}

\begin{tabular}{|c|c|c|c|c|c|c|c|c|c|c|}
\hline Variable & (1) & (2) & (3) & (4) & (5) & (6) & (7) & (8) & (9) & (10) \\
\hline $\begin{array}{l}\text { Non-R\&D expenditure as share of } \\
\text { (1) sales }(t-1)\end{array}$ & 1.00 & & & & & & & & & \\
\hline $\begin{array}{l}\text { R\&D expenditure as share of sales } \\
\text { (2) }(\mathrm{t}-1)\end{array}$ & 0.13 & 1.00 & & & & & & & & \\
\hline (3) Continuous R\&D activity (t-1) & 0.00 & 0.24 & 1.00 & & & & & & & \\
\hline $\begin{array}{l}\text { Share of employees with } \\
\text { (4) university degree (t-1) }\end{array}$ & 0.03 & 0.37 & 0.15 & 1.00 & & & & & & \\
\hline (5) Part of conglomerate & -0.06 & -0.09 & 0.12 & -0.05 & 1.00 & & & & & \\
\hline (6) Location in eastern Germany & 0.11 & 0.09 & 0.03 & 0.25 & -0.11 & 1.00 & & & & \\
\hline (7) Share of exports of sales & -0.07 & 0.10 & 0.32 & -0.09 & 0.20 & -0.28 & 1.00 & & & \\
\hline (8) No of employees (logs) & -0.12 & -0.12 & 0.28 & -0.26 & 0.32 & -0.19 & 0.35 & 1.00 & & \\
\hline (9) Public funding & 0.13 & 0.38 & 0.34 & 0.27 & -0.04 & 0.32 & 0.09 & 0.05 & 1.00 & \\
\hline (10) Patent protection & -0.06 & 0.27 & 0.38 & 0.06 & 0.14 & -0.14 & 0.39 & 0.33 & 0.24 & 1.00 \\
\hline (11) Year 2005 & -0.02 & 0.05 & -0.12 & 0.03 & 0.23 & 0.01 & -0.06 & -0.15 & -0.05 & -0.09 \\
\hline (12) Medium high-tech manufacturing & -0.03 & 0.07 & 0.24 & -0.03 & 0.09 & -0.07 & 0.41 & 0.17 & 0.12 & 0.33 \\
\hline (13) High-tech manufacturing & 0.00 & 0.27 & 0.17 & 0.18 & -0.04 & -0.04 & 0.08 & -0.02 & 0.09 & 0.18 \\
\hline (14) Distributive services & -0.07 & -0.15 & -0.23 & -0.10 & -0.02 & 0.06 & -0.22 & -0.09 & -0.15 & -0.17 \\
\hline (15) Knowledge-intensive services & -0.06 & -0.06 & -0.14 & 0.07 & -0.12 & -0.01 & -0.17 & -0.06 & -0.07 & -0.14 \\
\hline (16) Technological services & 0.09 & 0.21 & -0.02 & 0.59 & 0.01 & 0.16 & -0.21 & -0.29 & 0.06 & -0.07 \\
\hline Variance Inflation Factor (VIF) & 1.06 & 1.39 & 1.46 & 2.13 & 1.26 & 1.34 & 1.55 & 1.54 & 1.4 & 1.55 \\
\hline Variable & (11) & (12) & (13) & $(14$ & $(15)$ & (16) & (17) & (18) & (19) & $(20)$ \\
\hline (11) Year 2005 & 1.00 & & & & & & & & & \\
\hline (12) Medium high-tech manufacturing & -0.05 & 1.00 & & & & & & & & \\
\hline (13) High-tech manufacturing & -0.02 & -0.15 & 1.00 & & & & & & & \\
\hline (14) Distributive services & 0.15 & -0.20 & -0.11 & 1.00 & & & & & & \\
\hline (15) Knowledge-intensive services & -0.04 & -0.13 & -0.07 & -0.09 & 1.00 & & & & & \\
\hline (16) Technological services & 0.09 & -0.18 & -0.10 & -0.13 & -0.09 & 1.00 & & & & \\
\hline & 1.12 & 1.45 & 1.4 & 1.28 & 1.21 & 2.18 & & & & \\
\hline Mean VIF & 1.46 & & & & & & & & & \\
\hline
\end{tabular}

Appendix D: Results of ordinary least-squares regression analysis on Model II including variables on realised absorptive capacity

\begin{tabular}{|c|c|c|c|c|}
\hline \multirow[t]{2}{*}{ Model II } & \multicolumn{2}{|c|}{ Economic factor } & \multicolumn{2}{|c|}{ Knowledge factor } \\
\hline & Coef & Std err & Coef & Std err \\
\hline \multicolumn{5}{|l|}{ Innovation expenditure as share of sales ( $\mathrm{t}-1)$} \\
\hline Non-R\&D expenditure as share of sale (t-1) & $0.310 * * *$ & 0.097 & 0.022 & 0.117 \\
\hline $\mathrm{R} \& \mathrm{D}$ expenditure as share of sales $(\mathrm{t}-1)$ & 0.154 & 0.146 & 0235 & 0.109 \\
\hline Continuous R\&D activity $(\mathrm{t}-1)^{\dagger}$ & 0.054 & 0.022 & 0.017 & 0.018 \\
\hline Share of employees with university degree $(\mathrm{t}-1)^{\dagger}$ & 0.000 & 0.001 & -0.000 & 0.000 \\
\hline Customers as crucial information source $(\mathrm{t}-1)^{\dagger}$ & -0.013 & 0.023 & 0.007 & 0.018 \\
\hline Suppliers as crucial information source $(\mathrm{t}-1)^{\dagger}$ & -0.005 & 0.026 & $0.043^{*}$ & 0.021 \\
\hline Competitors as crucial information source $(\mathrm{t}-1)^{\dagger}$ & -0.031 & 0.048 & 0.025 & 0.043 \\
\hline Research facilities as crucial information source $(\mathrm{t}-1)^{\dagger}$ & $0.049 *$ & 0.028 & 0.006 & 0.022 \\
\hline Part of conglomerate ${ }^{\dagger}$ & 0.007 & 0.018 & 0.015 & 0.015 \\
\hline Location in eastern Germany $^{\dagger}$ & $-0.038 *$ & 0.020 & -0.051 & 0.016 \\
\hline Share of exports in sales & -0.122 & 0.041 & -0.015 & 0.035 \\
\hline No of employees (logs) & -0.016 & 0.008 & 0.012 & 0.006 \\
\hline
\end{tabular}




\begin{tabular}{|c|c|c|c|c|}
\hline \multirow[t]{2}{*}{ Model II } & \multicolumn{2}{|c|}{ Economic factor } & \multicolumn{2}{|c|}{ Knowledge factor } \\
\hline & Coef & Std err & Coef & Std err \\
\hline Public funding $^{\dagger}$ & 0.065 & 0.021 & -0.055 & 0.018 \\
\hline Patent protection ${ }^{\dagger}$ & -0.024 & 0.023 & 0.007 & 0.019 \\
\hline Year $2005^{\dagger}$ & -0.016 & 0.019 & -0.068 & 0.015 \\
\hline Medium high-tech manufacturing ${ }^{\dagger}$ & 0.003 & 0.025 & -0.007 & 0.020 \\
\hline High-tech manufacturing $^{\dagger}$ & 0.011 & 0.038 & -0.007 & 0.029 \\
\hline Distributive services $^{\dagger}$ & -0.037 & 0.029 & -0.024 & 0.023 \\
\hline Knowledge-intensive services ${ }^{\dagger}$ & 0.008 & 0.04 & -0.029 & 0.033 \\
\hline Technological services $^{\dagger}$ & -0.031 & 0.038 & 0.009 & 0.032 \\
\hline Constant & $0.631 * * *$ & 0.039 & 0.337 & 0.031 \\
\hline Number of observations & & 2685 & & 2685 \\
\hline $\mathrm{F}$ & $(20,664)$ & 3.84 & $(20,664)$ & 4.42 \\
\hline Prob $>$ F & & 0.00 & & 0.00 \\
\hline $\mathrm{R}^{2}$ & & 0.09 & & 0.11 \\
\hline Root MSE & & 0.22 & & 0.18 \\
\hline
\end{tabular}




\section{$9 \quad$ References}

Adner, R and D A Levinthal (2004), What Is Not a Real Option: Considering Boundaries for the Application of Real Options to Business Strategy, Academy of Management Review 29 (1), 74-85.

Bertrand, M and S Mullainathan (2001), Do People Mean What They Say? Implications for Subjective Survey Data, American Economic Review 91 (2), 67-72.

Black, F and M Scholes (1973), The Pricing of Options and Corporate Liabilities, Journal of Political Economy 81 (3), 637-654.

Bowman, E H and D Hurry (1993), Strategy through the Option Lens: An Integrated View of Resource Investments, Academy of Management Review 18 (4), 760-782.

Boyd, B, Dess, G and A Rasheed (1993), Divergence between Archival and Perceptual Measures of the Environment: Causes and Consequences, Academy of Management Review 18 (2), 204-226.

Brouwer, E and A H Kleinknecht (1997): Measuring the unmeasurable: A country's nonR\&D expenditure on product and service innovation, Research Policy 25, 1235-1242.

Chesbrough, H and R S Rosenbloom (2002), The Role of the Business Model in Capturing Value from Innovation: Evidence from Xerox Corporation's Technology Spin-Off Companies, Industrial \& Corporate Change 11 (3), 529-555.

Cohen, W M and D A Levinthal (1989), Innovation and Learning: The Two Faces of R\&D, The Economic Journal 99, 569-596.

Cohen, W M and D A Levinthal (1990), Absorptive Capacity: A New Perspective on Learning and Innovation, Administrative Science Quarterly 35 (1), 128-153.

Cohen, W M and D A Levinthal (1994), Fortune Favors the Prepared Firm, Management Science 40 (2), 227-251.

Cooper, R, S Edgett and E Kleinschmidt (2001), Portfolio Management for New Product Development: Results of an Industry Practices Study, R\&D Management 31 (4), 361 379.

Copeland, T and P Tufano (2004), A Real-World Way to Manage Real Options, Harvard Business Review 82 (3), 90-99.

Criscuolo, C, J E Haskel and M J Slaughter (2005), Global Engagement and the Innovation Activities of Firms, NBER Working Paper No. 11479, Cambridge, MA. 
Felder, J, G Licht, E Nerlinger and H Stahl (1996), Factors Determining R\&D and Innovation Expenditures in German Manufacturing Industries, in Kleinknecht, A H (edt), Determinants of Innovation: The Message from New Indicators, London 125-154.

Folta, T B and J P O'Brien (2004), Entry in the Presence of Dueling Options, Strategic Management Journal 25 (2), 121-138.

Frost, T S, J M Birkinshaw and P C Ensign (2002), Centers of Excellence in Multinational Corporations, Strategic Management Journal 23 (11), 997-1018.

Gourville, J.T. (2006), Eager Sellers \& Stony Buyers, Harvard Business Review 84 (6), 98106.

Grimpe, C and W Sofka (2008), Search Patterns and Absorptive Capacity: Low- and HighTechnology Sectors in European Countries, Research Policy forthcoming.

Grupp, H (1997), Messung und Erklärung des technischen Wandels, Grundzüge einer empirischen Innovationsökonomik, Berlin.

Heidenberger K and C Stummer (1999), Research and development project selection and resource allocation: a review of quantitative modelling approaches, International Journal of Management Reviews, 1 (2), 197-224.

Hipp, C and H Grupp (2005), Innovation in the service sector: The demand for servicespecific innovation measurement concepts and typologies, Research Policy 34, 517 535.

Jansen, J J P, F A J Van den Bosch and H W Volberda (2005), Managing Potential and Realized Absorptive Capacity: How Do Organizational Antecendents Matter?, Academy of Management Journal 48 (6), 999-1015.

Jansen, J J P, F A J Van Den Bosch and H W Volberda (2006), Exploratory Innovation, Exploitative Innovation, and Performance: Effects of Organizational Antecedents and Environmental Moderators, Management Science 52 (11), 1661-1674.

Janz, N, G Ebling, S Gottschalk and H Niggemann (2001), The Mannheim Innovation Panels (MIP and MIP-S) of the Centre for European Economic Research (ZEW), Journal of Applied Social Science Studies 121 (1), 123-129.

Kaiser, H F and J Rice (1974), Little Jiffy, Mark Iv, Educational and Psychological Measurement 34, 111-117.

Kester, W C (1984), Today's options for tomorrow's growth, Harvard Business Review 62 (2), 153-160.

Kleinknecht, A H (1987), Measuring R\&D in Small Firms: How Much Are We Missing?, Journal of Industrial Economics 36, 253-256.

Kline, S J and N Rosenberg (1986), “An Overview of Innovation”, in Landau, R and N Rosenberg (eds), The Positive Sum Strategy. Harnessing Technology for Economic Growth, National Academy Press, Washington, DC.. 
Knight, F H (1921), Risk, Uncertainty, and Profit, Boston.

Lane, PJ, BR Koka and S Pathak (2006), The Reification of Absorptive Capacity: A Critical Review and Rejuvenation of the Construct, Academy of Management Review 31 (4), 833-863.

Laursen, K and A Salter (2006), Open for Innovation: The Role of Openness in Explaining Innovation Performance among U.K. Manufacturing Firms, Strategic Management Journal 27 (2), 131-150.

Lawrence, P and Lorsch, J (1967), Organization and Environment, Harvard University Press Cambridge

Loch, C H, M E Solt and E M Bailey (2008), Diagnosing Unforeseeable Uncertainty in a New Venture, Journal of Product Innovation Management 25 (1), 28-46.

Maher, P M and A H Rubenstein (1974), Factors Affecting Adoption of a Quantitative Method for R\&D Project Selection, Management Science 21 (2), 119-129.

March, J G (1991), Exploration and Exploitation in Organizational Learning, Organization Science 2 (1), 71-87.

McGrath, R G (2001), Exploratory Learning, Innovative Capacity, and Managerial Oversight, Academy of Management Journal 44 (1), 118-131.

O'Connor, G C and R W Veryzer (2001), The Nature of Market Visioning for TechnologyBased Radical Innovation, Journal of Product Innovation Management 18 (4), 231246.

OECD and Eurostat (1997) "Proposed Guidelines for collecting and interpreting technological innovation data - Oslo Manual", Paris.

Pavitt, K, M Robson and J Townsend (1989), Technological Accumulation, Diversification and Organization in UK Companies, 1945-1983, Management Science 35, 81-99.

Perlitz, M, T Peske and R Schrank (1999), Real options evaluation: the new frontier in R\&D project evaluation?, R\&D Management Journal 29 (3), 255-269.

Pich, M T, C H Loch and A De Meyer (2002), On Uncertainty, Ambiguity, and Complexity in Project Management, Management Science 48 (8), 1008-1023.

Pindyck, R S (1991), Irreversibility, Uncertainty, and Investment, Journal of Economic Literature 29 (3), 1110-1148.

Rammer, C, B Peters, T Schmidt, B Aschhoff, T Doherr and H Niggemann (2005), Innovationen in Deutschland - Ergebnisse der Innovationserhebung 2003 in der deutschen Wirtschaft, ZEW Wirtschaftsanalysen Band 78, Nomos Verlagsgesellschaft, Baden-Baden. 
Rothwell, R and M Dodgson (1991), External Linkages and Innovation in Small and MediumSized Enterprises, R\&D Management 21, 125-137.

Subramaniam, M and M A Youndt (2005), The Influence of Intellectual Capital on the Types of Innovative Capabilities, Academy of Management Journal 48 (3), 450-463.

Trigeorgis, L (1993), Real Options and interactions with financial flexibility, Financial Management 22 (3), 202-224.

Trigeorgis, L (1997), Real Options: Managerial Flexibility and Strategy in Resource Allocation, MIT Press, Cambridge, Mass.

Zahara, S A and G George (2002), Absorptive Capacity: A Review, Reconceptualization and Extension, Academy of Management Journal 27 (2), 185-203.

Zaheer, S (1995), Overcoming the Liability of Foreignness., Academy of Management Journal 38 (2), 341-364.

Zahra, S A and G George (2002), Absorptive Capacity: A Review and Reconceptualization, and Extension, Academy of Management Review 27 (2), 185-203. 